\title{
Thiasyrbactins Induce Cell Death via Proteasome Inhibition in Multiple Myeloma Cells
}

\author{
MARQUICIA R. PIERCE ${ }^{1}$, NICOLE A. BAKAS ${ }^{2}$, MICHAEL C. PIRRUNG ${ }^{2,3}$ and ANDRÉ S. BACHMANN ${ }^{1}$ \\ ${ }^{1}$ Department of Pediatrics and Human Development, Michigan State University, Grand Rapids, MI, U.S.A.; \\ ${ }^{2}$ Department of Chemistry, University of California, Riverside, CA, U.S.A.; \\ ${ }^{3}$ Department of Pharmaceutical Sciences, University of California, Irvine, CA, U.S.A.
}

\begin{abstract}
Background/Aim: Proteasome inhibition is a validated therapeutic strategy for the treatment of refractory and relapsed multiple myeloma (MM) and mantle cell lymphoma. We previously showed that thiasyrbactins (NAM compounds) are inhibitors with an affinity for the trypsin-like $(T-L, \beta 2)$ site of the constitutive proteasome, and more profoundly for the T-L site of the immunoproteasome. Materials and Methods: In this study, the biological activity of three NAM compounds was evaluated using four MM cell lines (ARD, U266, MMIR, and MMIS). We assessed the effect of (NAM-93, NAM-95, and NAM-105 on cell viability, as well as cell-based proteasomal activities, and determined the $E_{50}$ and $\mathrm{Ki}_{50}$ values, respectively. Results: MM cells were most sensitive to NAM-93 with $E C_{50}$ values $<0.75 \mu M$ after $48 \mathrm{~h}$ of treatment. NAM-105 had a similar profile in most of the MM cells with $E C_{50}$ values ranging between 0.42 and $3.02 \mu \mathrm{M}$. The level of inhibition of the proteasome T-L sub-catalytic activity in actively-growing MM cells was similar for NAM93 and NAM-105. However, in each cell line, NAM-93 was more effective than NAM-105 at inhibiting overall trypsin-like sub-catalytic activity while NAM-105 was typically more effective at inhibiting overall chymotrypsin-like (CT-L, $\beta 5)$ sub-catalytic activity. Conclusion: These results show for the first time the proteasome-targeted biological activity of thiasyrbactins in MM tumor cells.
\end{abstract}

The proteasome is involved in a vast number of functions within normal cells. It is also heavily involved in the pathologic progress of several disease states including

Correspondence to: André S. Bachmann, Michigan State University, College of Human Medicine, Department of Pediatrics and Human Development, 400 Monroe Avenue NW, Grand Rapids, MI 49503, U.S.A. Tel: +1 6162342841, e-mail: andre.bachmann@hc.msu.edu

Key Words: Proteasome inhibitors, immunoproteasome, NAM, thiasyrbactin, caspase-like, trypsin-like, chymotrypsin-like activity, multiple myeloma. hematological cancers, autoimmune disorders, and inflammatory diseases. The active core of the proteasome has 2 protein rings, each consisting of 7 subunits $(\beta 1-\beta 7)$. Three of these subunits perform a catalytic step in degrading proteins. They are denoted $\beta 1$ (caspase-like, C-L), $\beta 2$ (trypsin-like, T-L), and $\beta 5$ (chymotrypsin-like, CT-L). The activity of the subunits varies depending on the proteasome isoform. In addition to the constitutive proteasome, other isoforms include the immunoproteasome, which is induced in inflammation and via the action of certain cytokines (e.g., interferon $\gamma)(1-5)$.

Proteasome inhibition is a validated therapeutic strategy against several forms of cancer $(3,6)$. Indeed, FDAapproved proteasome inhibitors, bortezomib (BTZ), ixazomib (IXA), and carfilzomib (CAR) have had clinical success in hematological cancers such as multiple myeloma (MM) and mantle cell lymphoma (7-10). Bortezomib and ixazomib are part of the boronate class, while carfilzomib is part of the epoxyketone class. These proteasome inhibitors effectively target the constitutive proteasome. More recently, the immunoproteasome has become the target of nextgeneration proteasome inhibitors particularly in autoimmune disorders and inflammatory diseases (11-13).

The syrbactins are a new class of natural products-based proteasome inhibitors that selectively and covalently bind to the catalytic Thr1 residue of the proteasome by a novel mechanism (14). Syrbactins include glidobactins (15-19), cepafungins $(20,21)$, and syringolins $(1,3,14,22,23)$. Although glidobactins and cepafungins have been described many years ago, the mode of action (proteasome inhibition) remained elusive until recently (14). Our discovery spurred multiple investigations into elucidating the total synthesis of the natural products Syringolin A/B (SylA/B) (24-26). This prompted the design of a number of syrbactin-inspired analogs with improved biological activity and anti-proliferative potency (26-35). TIR-203 was inspired by SylB and inhibits proteasome activity and growth of multiple myeloma and neuroblastoma (NB) cell lines (35). The syrbactin structural analog TIR-199 was the first syrbactin to show efficacy in an in vivo cancer 


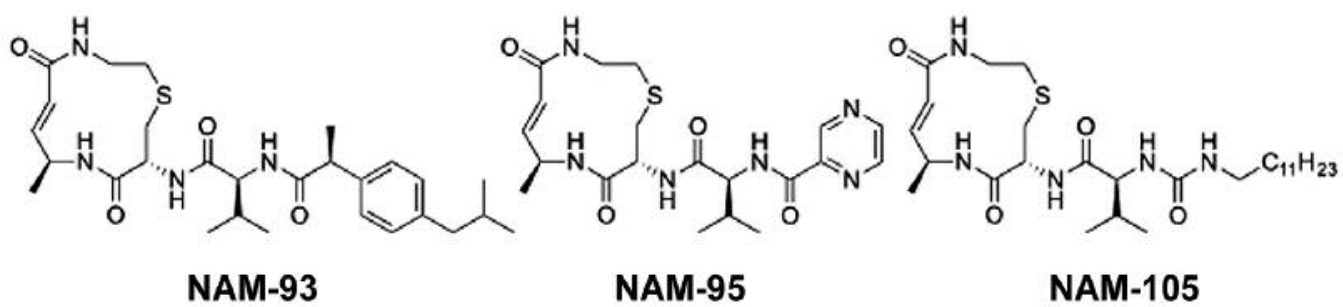

Figure 1. Structures of thiasyrbactins representing novel syrbactin-based proteasome inhibitors. The molecular weights for NAM-93, NAM-95, and NAM-105 are 531, 449, and 554 Da, respectively.

model (29), and both TIR-203 and TIR-199 were also investigated by the National Cancer Institute, Developmental Therapeutics Program (NCI-DTP). In an attempt to make improvements to the TIR-199 molecule, the NAM family of analogs was designed (30). NAM-105 was inspired by TIR199, as most of its structure is similar except for the isolated alkene. NAM-93 and NAM-95 were specifically designed to improve solubility. Recently, we reported that these thiasyrbactins preferentially inhibited the T-L $(\beta 2 \mathrm{i})$ subunit of the immunoproteasome using an in vitro proteasomal activity assay that relies on purified immunoproteasomes (30). In this study, we present evidence that these thiasyrbactins pass the cell membrane and induce cell death of actively-dividing MM cells via inhibition of the proteasome.

\section{Materials and Methods}

Chemical reagents. Thiasyrbactins (NAM-93, NAM-95, and NAM105) were synthesized as reported (30) and solubilized in DMSO solution (Figure 1). Bortezomib (Velcade ${ }^{\circledR}$ ) was purchased from LC Laboratories (Woburn, MA, USA). All drug solutions were prepared at $10 \mathrm{mM}$ in DMSO (NAMs and bortezomib), sterile-filtered, and stored frozen at $-80^{\circ} \mathrm{C}$. At the beginning of each experiment, aliquots were thawed and diluted to the final concentration.

Mammalian cell cultures and reagents. Authenticated human MM cell lines were obtained from certified suppliers between 2014 and 2016. ARD (Van Andel Research Institute, Grand Rapids, MI, USA); U266 (Van Andel Research Institute); MM1R (ATCC, Manassas, VA, USA), MM1S (ATCC). MM1R cell line derived from a patient who had become resistant to steroid-based therapy, dexamethasone. All cell lines were maintained in Roswell Park Memorial Institute (RPMI) 1640 medium containing 10\% (v/v) heat-inactivated fetal bovine serum (Invitrogen, Carlsbad, CA, USA) and supplemented with penicillin $(100 \mathrm{U} / \mathrm{ml})$ and streptomycin $(100 \mu \mathrm{g} / \mathrm{ml})$. Cells were cultured at $37^{\circ} \mathrm{C}$ in a humidified atmosphere containing $5 \% \mathrm{CO}_{2}$ and plated $24 \mathrm{~h}$ before drug treatment. Control cells were treated with $1 \%$ DMSO in culture media, equivalent to the maximum amount of DMSO present at the highest doses of drug.

Cell viability assay. The RealTime-Glo Assay (Promega, Madison, WI, USA) was used to determine the viability of cancer cells after 24 and $48 \mathrm{~h}$ treatment. Cells were seeded at 10,000 cells/well in solid white 96-well plates with media containing RealTime-Glo reagents as specified by the manufacturer's instructions. Luminescence was measured with a Biotek Synergy microplate reader at 0 and $24 \mathrm{~h}$ after seeding and again after $24 \mathrm{~h}$ and $48 \mathrm{~h}$ of drug treatment. Data were expressed as relative light units and normalized to the well with the highest concentration of DMSO.

Cell-based proteasome activity assay. The cell culture-based proteasome-Glo inhibition assay (Promega) was performed as previously described (29). Cells were seeded in solid white 96-well plates $24 \mathrm{~h}$ prior to treatment. Cells were then treated with $0-10 \mu \mathrm{M}$ of indicated drug for $24 \mathrm{~h}$. Cells were incubated for $15 \mathrm{~min}$ with the proteasome Glo $^{\mathrm{TM}}$ reagents according to the manufacturer's instructions and the inhibition of the proteasomal sub-catalytic activities (C-L, T-L, CT-L) were measured by addition of luminogenic substrates Z-nLPnLD-aminoluciferin, Z-LRRaminoluciferin, and Suc-LLVY-aminoluciferin, respectively.

Statistical analyses. GraphPad Prism v7.04 was used to generate cell viability $\left(\mathrm{EC}_{50}\right)$ curves and proteasome inhibition $\left(\mathrm{Ki}_{50}\right)$ curves. The $\mathrm{EC}_{50}$ values were determined from a non-linear regression fit as $\log$ (inhibitor) $v s$. response, variable slope (four parameters). $\mathrm{Ki}$ values were determined from a non-linear regression fit as [inhibitor] $v s$. normalized response.

\section{Results}

NAM compounds have distinct cell viability profiles. Previous studies from our group have demonstrated the extent of constitutive proteasome and immunoproteasome inhibition by thiasyrbactins (NAMs) using an in vitro-based proteasomal activity assay. The tested NAM compounds predominantly inhibited the CT-L and T-L activities of the constitutive proteasome, but also potently and selectively inhibited the T-L activity of the immunoproteasome, with little effect on the CT-L and C-L sub-catalytic sites (30).

In this study, the effects of NAM-93, NAM-95, and NAM105 were firstly assessed on the viability of actively-dividing MM tumor cell lines ARD, U266, MM1R, and MM1S. As a positive control, bortezomib (BTZ) was included at one single concentration $(0.05 \mu \mathrm{M})$. Even though the three NAM compounds have similar in vitro effects on the sub-catalytic activities of the constitutive proteasome and immuno- 

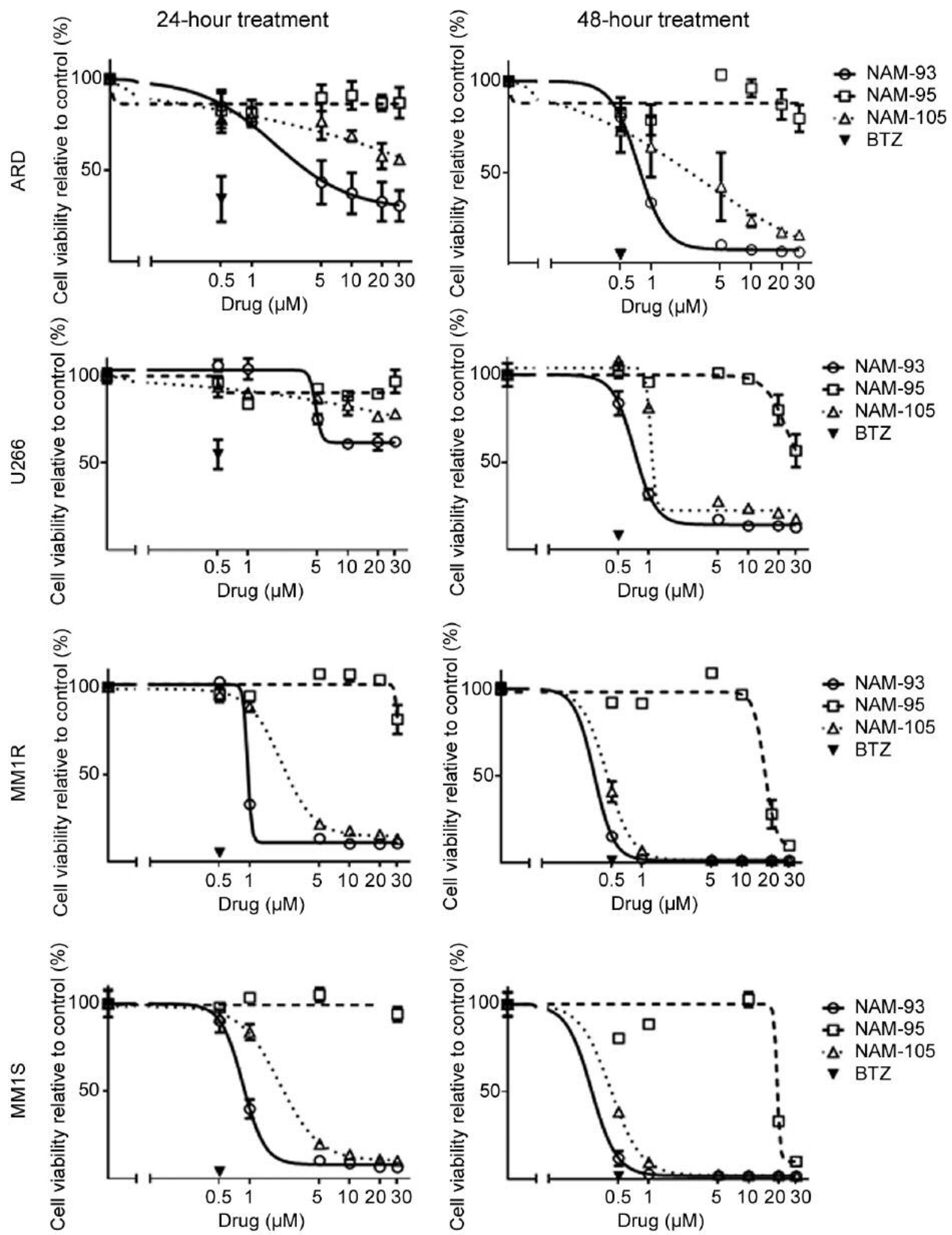

Figure 2. NAM compounds have distinct cell viability profiles. Cell viability was determined at 24 h and 48 h after exposure of multiple myeloma (MM) cell lines, ARD, U266, MM1R, and MM1S to proteasome inhibitors NAM-93, NAM-95, and NAM-105. Bortezomib (BTZ) was used as a positive control. Cell viability was inhibited in a dose-dependent manner. Data was collected from three individual experiments $(n=3)$. The $E C_{50}$ values were determined from a non-linear regression fit as log(inhibitor) vs. response, variable slope (four parameters). See Table I for numeric EC 50 values. 
proteasome, their cell viability profiles were markedly different. Figure 2 shows that the MM cells were most sensitive to NAM-93 after 24 and $48 \mathrm{~h}$ with $\mathrm{EC}_{50}$ values $<0.75 \mu \mathrm{M}$ (determined at $48 \mathrm{~h}$ ). Of note, the dexamethasoneresistant cell line MM1R and the dexamethasone-sensitive cell line MM1S responded in a similar manner to NAM-93. NAM-105 demonstrated a comparable profile in most MM cells with $\mathrm{EC}_{50}$ values ranging between 0.42 and $3.02 \mu \mathrm{M}$. In contrast, NAM-95 showed significantly higher $\mathrm{EC}_{50}$ values, from 16.93 to $>30 \mu \mathrm{M}$. $\mathrm{EC}_{50}$ values are displayed in Table I. NAM compounds have distinct proteasome inhibition profiles. To assess if the three NAM compounds have the same proteasome inhibition profile in cells as previously observed in our in vitro experiments (30), a cell-based proteasome activity assay was used to measure the three subcatalytic activities in four MM cell lines. Figure 3 shows the dose-dependent inhibitory effects of NAM-93, NAM-95, and NAM-105 on the C-L, T-L, and CT-L sub-catalytic activities of the proteasome. The $\mathrm{Ki}_{50}$ numeric values for the overall (constitutive and immunoproteasome) sub-catalytic activities, after a 24-h incubation with NAM compounds are displayed in Table II.

NAM-93 inhibited all three active sites (C-L, T-L, and CT-L) in four MM cell lines. NAM-93 was the least selective for the $\mathrm{C}$ - $\mathrm{L}$ site $\left(\mathrm{Ki}_{50}\right.$ values $\left.1.1-5.3 \mu \mathrm{M}\right)$ and was most selective in inhibiting the $\mathrm{T}-\mathrm{L}$ site with $\mathrm{Ki}_{50}$ values as low as $0.27 \mu \mathrm{M}-1.0 \mu \mathrm{M}$. This is likely due to the fact that the T-L site is the only active site inhibited by NAM-93 in both the constitutive and immunoproteasome isoform. NAM-95 showed selectivity for the CT-L site with $\mathrm{Ki}_{50}$ values $\sim 7.5 \mu \mathrm{M}$ in two of the four cell lines. NAM-105 inhibited each of the three active sites in all four cell lines and showed specificity for the CT-L site with $\mathrm{Ki}_{50}$ values as low as $0.10-1.08 \mu \mathrm{M}$.

Despite the similar in vitro inhibition profiles for CT-L and T-L sites (30), NAM-95 was the least effective NAM and inhibited the proteasomal activity with $\mathrm{Ki}_{50}$ values ranging from 7.5 to over $10 \mu \mathrm{M}$ in all four cell lines. When comparing the NAM-93 and NAM-105 profiles, C-L inhibition was similar between the four cell lines. However, in each cell line, NAM-93 was more effective than NAM105 at inhibiting the T-L sub-catalytic activity, while NAM105 was usually more effective at inhibiting the CT-L subcatalytic activity.

\section{Discussion}

The immunoproteasome is a next-generation target for proteasome inhibitors for hematologic malignancies, autoimmune diseases, and immune disorders (4). NAM compounds have been shown to inhibit the T-L subunit of the immunoproteasome. As these compounds had moderate biological activities against NB cells (30), we here tested the
Table I. NAM syrbactin analog-induced inhibition of cell viability displayed as $E_{50}(\mu M)$ values for 24 - and 48 -h treatments. NAM-93 is the most potent analog across multiple myeloma (MM) cell lines. Data calculated from Figure 2.

24-Hour cell viability, $\mathrm{EC}_{50}(\mu \mathrm{M})$

\begin{tabular}{lccc}
\hline & NAM-93 & NAM-95 & NAM-105 \\
\hline ARD & 1.72 & $>30$ & $>30$ \\
U266 & $>30$ & $>30$ & $>30$ \\
MM1R & 0.95 & $>30$ & 2.08 \\
MM1S & 0.85 & $>30$ & 1.99 \\
\hline 48-Hour cell viability, EC $50(\mu \mathrm{M})$ & & \\
\hline & \multirow{2}{*}{ NAM-93 } & NAM-95 & NAM-105 \\
\hline ARD & 0.75 & $>30$ & 3.02 \\
U266 & 0.72 & 24.31 & 1.05 \\
MM1R & 0.33 & 16.93 & 0.44 \\
MM1S & 0.27 & 19.27 & 0.42 \\
\hline
\end{tabular}

Table II. NAM syrbactin analog-induced inhibition of cell-based proteasome sub-catalytic activities displayed as $\mathrm{Ki}_{50}(\mu \mathrm{M})$ values. Data calculated from Figure 3.

Cell-based proteasome inhibition, $\mathrm{Ki}_{50}(\mu \mathrm{M})$

\begin{tabular}{cccc}
\hline & NAM-93 & NAM-95 & NAM-105 \\
\hline ARD & & & \\
C-L & $1.11 \pm 0.32$ & $>10$ & $0.91 \pm 0.14$ \\
T-L & $0.27 \pm 0.08$ & $>10$ & $1.01 \pm 0.33$ \\
CT-L & $0.50 \pm 0.14$ & $7.5 \pm 1.9$ & $0.10 \pm 0.02$ \\
U266 & & & \\
C-L & $5.31 \pm 0.64$ & $>10$ & $6.99 \pm 1.15$ \\
T-L & $1.00 \pm 0.29$ & $9.49 \pm 1.79$ & $4.07 \pm 0.51$ \\
CT-L & $0.85 \pm 0.16$ & $>10$ & $1.08 \pm 0.16$ \\
MM1R & & & \\
C-L & $2.17 \pm 0.48$ & $>10$ & $1.67 \pm 0.35$ \\
T-L & $0.32 \pm 0.04$ & $>10$ & $1.38 \pm 0.25$ \\
CT-L & $0.80 \pm 0.16$ & $>10$ & $0.53 \pm 0.07$ \\
MM1S & & & \\
C-L & $2.59 \pm 0.56$ & $>10$ & $3.98 \pm 1.14$ \\
T-L & $0.42 \pm 0.10$ & $>10$ & $2.22 \pm 0.39$ \\
CT-L & $0.80 \pm 0.22$ & $7.51 \pm 1.68$ & $0.50 \pm 0.09$ \\
\hline
\end{tabular}

effects of these compounds on four MM tumor cell lines. In cell viability assessments, the $\mathrm{EC}_{50}$ values for NAM-93 and NAM-105 were $<2.08 \mu \mathrm{M}$ across all MM cell lines with submicromolar concentrations for NAM-93. NAM-95 had the least effect on cell viability, which was expected as it also had the weakest inhibitory activity of the proteasome. 
Caspase-like (C-L) activity
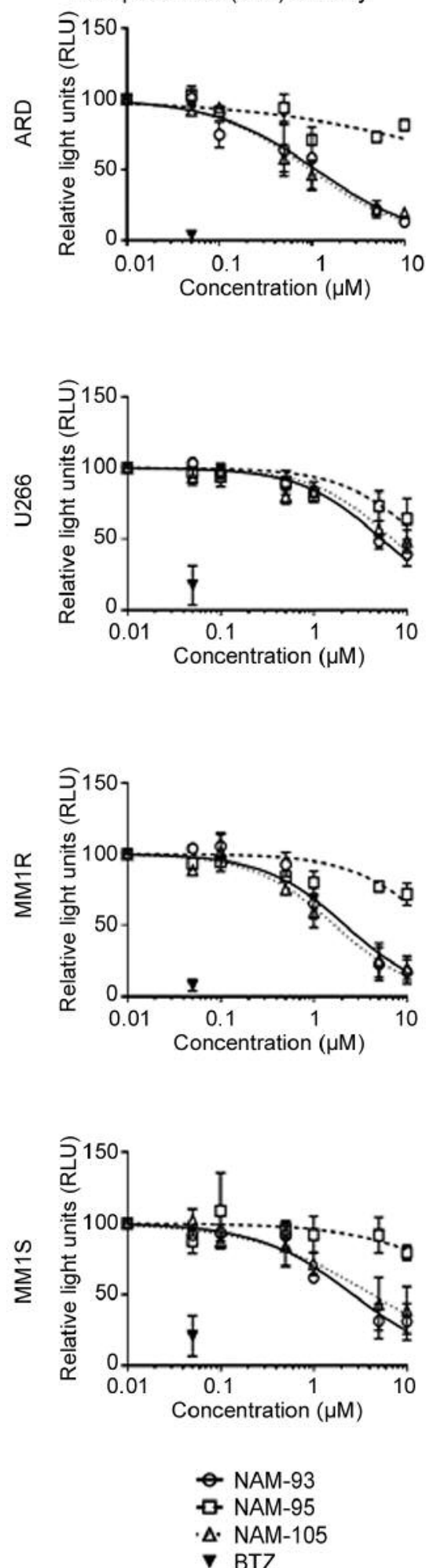

Trypsin-like (T-L) activity
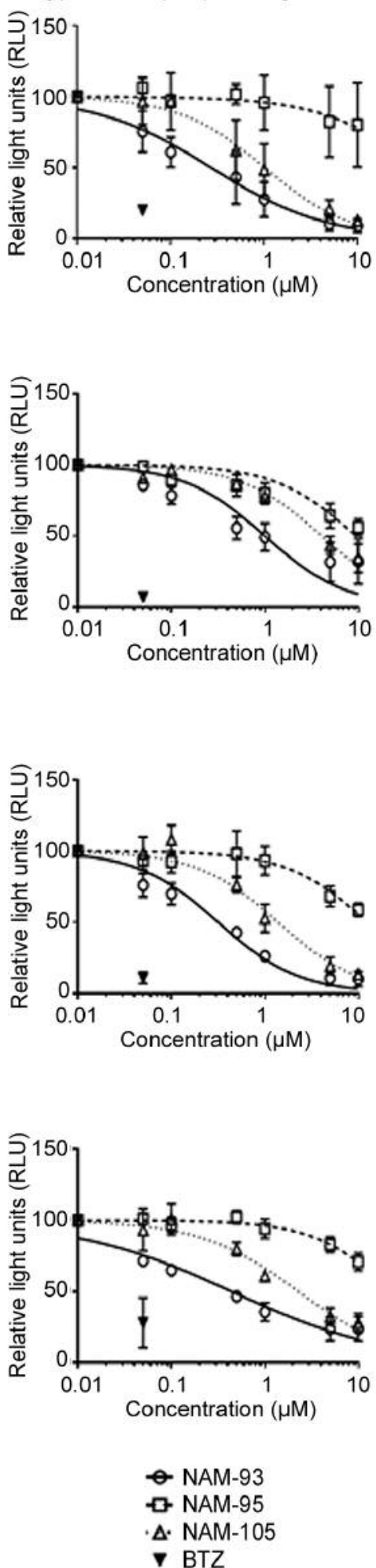

Chymotrypsin-like (CT-L) activity
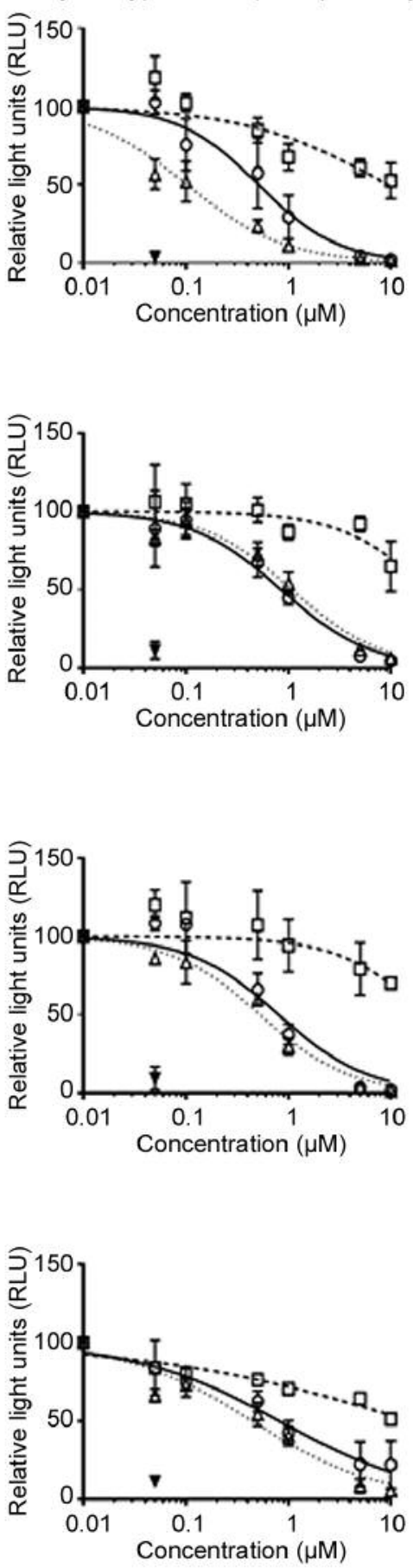

NAM-93

ㄴ. NAM-95

A. NAM-105

$\nabla \mathrm{BTZ}$

Figure 3. NAM compounds have distinct overall proteasome inhibition profiles. Multiple myeloma (MM) cell lines, ARD, U266, MM.1R, and MM.1S were exposed to proteasome inhibitors NAM-93, NAM-95, and NAM-105 for 24h. Bortezomib (BTZ) was used as a positive control. Cell-based proteasome activity was inhibited in a dose-dependent manner. Data were collected from three individual experiments $(n=3)$. Ki $i_{50}$ values were determined from a non-linear regression fit as [inhibitor] vs. normalized response. See Table II for numeric Ki $i_{50}$ values. 
As the cell-based proteasome activity assay is not able to distinguish between constitutive proteasomes and immunoproteasomes, our results assess overall proteasomal activity and not the contribution of each isoform. However, the MM cell lines do contain both constitutive proteasome and immunoproteasome $(36,37)$, which is likely why the anti-proliferative effect of the three NAM compounds are more pronounced in the MM cells versus the NB cells.

Our new results are promising and justify the further exploration of NAM compounds in immune and cancer cells. Our data show for the first time the biological activity of the thiasyrbactins in a hematological malignancy cell culture model. Cells that express higher proportions of immunoproteasome compared to constitutive proteasome may exhibit a marked increase in proteasomal inhibition and cell death. Under these conditions, synergistic effects might be observed in combination with other proteasome inhibitors, chemotherapeutic and antiviral drugs $(38,39)$ or immune-modulatory agents.

\section{Conflicts of Interest}

M.C.P., N.A.B., and A.S.B. are named inventors on a United States patent application concerning the thiasyrbactins. A.S.B is also a named inventor of United States patent (US 8,597,904, December 3, 2013) that relates to pharmaceutical compositions for the treatment of conditions responsive to proteasome inhibition. M.C.P and A.S.B are the founders of Hibiskus Biopharma, Inc (Kalamazoo, MI, USA). No potential conflicts of interest were disclosed by the other Authors.

\section{Acknowledgements}

This study was supported by MSU-internal funds to A.S. Bachmann. Marquicia Pierce was supported by Spartan Innovations (East Lansing, MI). The Authors thank Chad R. Schultz (Department of Pediatrics and Human Development, Michigan State University) for his expert technical support and scientific discussions throughout this study.

\section{References}

1 Kisselev AF: Joining the army of proteasome inhibitors. Chem Biol 15: 419-421, 2008

2 Kisselev AF and Groettrup M: Subunit specific inhibitors of proteasomes and their potential for immunomodulation. Curr Opin Chem Biol 23: 16-22, 2014

3 Kisselev AF, van der Linden WA and Overkleeft HS: Proteasome inhibitors: an expanding army attacking a unique target. Chem Biol 19: 99-115, 2012.

4 Murata S, Takahama Y, Kasahara M and Tanaka K: The immunoproteasome and thymoproteasome: functions, evolution and human disease. Nat Immunol 19: 923-931, 2018.

5 Piccinini M, Rinaudo MT, Anselmino A, Ramondetti C, Buccinna B, Fiano V, Ghimenti C and Schiffer D: Characterization of the $20 \mathrm{~S}$ proteasome in human glioblastomas. Anticancer Res 25: 3203$3210,2005$.

6 Kisselev AF and Goldberg AL: Proteasome inhibitors: from research tools to drug candidates. Chem Biol 8: 739-758, 2001.
7 Sugumar D, Keller J and Vij R: Targeted treatments for multiple myeloma: specific role of carfilzomib. Pharmgenomics Pers Med 8: 23-33, 2015

8 Barr P, Fisher R and Friedberg J: The role of bortezomib in the treatment of lymphoma. Cancer Invest 25: 766-775, 2007.

9 Torimoto Y, Shindo M, Ikuta K and Kohgo Y: Current therapeutic strategies for multiple myeloma. Int J Clin Oncol 20: 423-430, 2015.

10 Mian M, Tinelli M, E DEM, Turri G, Meneghini V, Pescosta N, Berno T, Marabese A, Mondello P, Patriarca F, Pizzolo G, Semenzato G, Cortelazzo S and Zambello R: Bortezomib, thalidomide and lenalidomide: Have they really changed the outcome of multiple myeloma? Anticancer Res 36: 1059-65, 2016.

11 Arimochi H, Sasaki Y, Kitamura A and Yasutomo K: Dysfunctional immunoproteasomes in autoinflammatory diseases. Inflamm Regen 36: 13, 2016.

12 Basler M, Mundt S, Bitzer A, Schmidt C and Groettrup M: The immunoproteasome: a novel drug target for autoimmune diseases. Clin Exp Rheumatol 33: S74-79, 2015.

13 Ogorevc E, Schiffrer ES, Sosic I and Gobec S: A patent review of immunoproteasome inhibitors. Expert Opin Ther Pat 28: 517540, 2018.

14 Groll M, Schellenberg B, Bachmann AS, Archer CR, Huber R, Powell TK, Lindow S, Kaiser M and Dudler R: A plant pathogen virulence factor inhibits the eukaryotic proteasome by a novel mechanism. Nature 452: 755-758, 2008.

15 Numata K, Murakami T, Oka M, Yamamoto H, Hatori M, Miyaki T, Oki T and Kawaguchi H: Enhanced production of the minor components of glidobactins in Polyangium brachysporum. J Antibiot 41: 1358-1365, 1988.

16 Numata K, Oka M, Nakakita Y, Murakami T, Miyaki T, Konishi M, Oki T, Kawaguchi H: Enzymatic formation of glidobactamine: a peptide nucleus of glidobactins A, B and C, new lipopeptide antitumor antibiotics. J Antibiot 41: 1351-1357, 1988.

17 Oka M, Nishiyama Y, Ohta S, Kamei H, Konishi M, Miyaki T, Oki T and Kawaguchi H: Glidobactins A, B and C, new antitumor antibiotics. I. Production, isolation, chemical properties and biological activity. J Antibiot 41: 1331-1337, 1988.

18 Oka M, Ohkuma H, Kamei H, Konishi M, Oki $\mathrm{T}$ and Kawaguchi $\mathrm{H}$ : Glidobactins $\mathrm{D}, \mathrm{E}, \mathrm{F}, \mathrm{G}$ and $\mathrm{H}$; minor components of the antitumor antibiotic glidobactin. J Antibiot 41: 1906-1909, 1988.

19 Oka M, Yaginuma K, Numata $K$, Konishi $M$, Oki $T$ and Kawaguchi H: Glidobactins A, B and C, new antitumor antibiotics. II. Structure elucidation. J Antibiot 41: 1338-1350, 1988.

20 Shoji J, Hinoo H, Kato T, Hattori T, Hirooka K, Tawara K, Shiratori O and Terui Y: Isolation of cepafungins I, II and III from Pseudomonas species. J Antibiot 43: 783-787, 1990.

21 Terui Y, Nishikawa J, Hinoo H, Kato T and Shoji J: Structures of cepafungins I, II and III. J Antibiot 43: 788-795, 1990.

22 Krahn D, Ottmann C and Kaiser M: The chemistry and biology of syringolins, glidobactins and cepafungins (syrbactins). Nat Prod Rep 28: 1854-1867, 2011.

23 Coleman CS, Rocetes JP, Park DJ, Wallick CJ, Warn-Cramer BJ, Michel K, Dudler R and Bachmann AS: Syringolin A, a new plant elicitor from the phytopathogenic bacterium Pseudomonas syringae pv. syringae, inhibits the proliferation of neuroblastoma and ovarian cancer cells and induces apoptosis. Cell Prolif 39: 599-609, 2006 
24 Clerc J, Groll M, Illich DJ, Bachmann AS, Huber R, Schellenberg B, Dudler R and Kaiser M: Synthetic and structural studies on syringolin A and B reveal critical determinants of selectivity and potency of proteasome inhibition. Proc Natl Acad Sci USA 106: 6507-6512, 2009.

25 Pirrung MC, Biswas G and Ibarra-Rivera TR: Total synthesis of syringolin A and B. Org Lett 12: 2402-2405, 2010.

26 Clerc J, Schellenberg B, Groll M, Bachmann AS, Huber R, Dudler R and Kaiser M: Convergent synthesis and biological evaluation of syringolin A and derivatives as eukaryotic $20 \mathrm{~S}$ proteasome inhibitors. Eur J Org Chem 21: 3991-4003, 2010.

27 Archer CR, Groll M, Stein ML, Schellenberg B, Clerc J, Kaiser M, Kondratyuk TP, Pezzuto JM, Dudler R and Bachmann AS: Activity enhancement of the synthetic syrbactin proteasome inhibitor hybrid and biological evaluation in tumor cells. Biochemistry 51: 6880-6888, 2012.

28 Archer CR, Koomoa D-LT, Mitsunaga EM, Clerc J, Shimizu M, Kaiser M, Schellenberg B, Dudler R and Bachmann AS: Syrbactin class proteasome inhibitor-induced apoptosis and autophagy occurs in association with p53 accumulation and Akt/PKB activation in neuroblastoma. Biochem Pharmacol 80: 170-178, 2010.

29 Bachmann AS, Opoku-Ansah J, Ibarra-Rivera TR, Yco LP, Ambadi S, Roberts CC, Chang CE and Pirrung MC: Syrbactin Structural analog TIR-199 blocks proteasome activity and induces tumor cell death. J Biol Chem 291: 8350-8362, 2016.

30 Bakas NA, Schultz CR, Yco LP, Roberts CC, Chang CA, Bachmann AS and Pirrung MC: Immunoproteasome inhibition and bioactivity of thiasyrbactins. Bioorg Med Chem 26: 401412, 2018

31 Clerc J, Florea BI, Kraus M, Groll M, Huber R, Bachmann AS, Dudler R, Driessen C, Overkleeft HS and Kaiser M: Syringolin A selectively labels the $20 \mathrm{~S}$ proteasome in murine EL4 and wild-type and bortezomib-adapted leukaemic cell lines. Chembiochem 10: 2638-2643, 2009.

32 Clerc J, Li N, Krahn D, Groll M, Bachmann AS, Florea BI, Overkleeft HS and Kaiser M: The natural product hybrid of Syringolin A and Glidobactin A synergizes proteasome inhibition potency with subsite selectivity. Chem Commun 47: 385-387, 2011
33 Ibarra-Rivera TR, Opoku-Ansah J, Ambadi S, Bachmann AS and Pirrung MC: Syntheses and cytotoxicity of syringolin B-based proteasome inhibitors. Tetrahedron 67: 9950-9956, 2011.

34 Kitahata S, Chiba T, Yoshida T, Ri M, Iida S, Matsuda A and Ichikawa S: Design, synthesis, and biological activity of isosyringolin A. Org Lett 18: 2312-2315, 2016.

35 Opoku-Ansah J, Ibarra-Rivera TR, Pirrung MC and Bachmann AS: Syringolin B-inspired proteasome inhibitor analogue TIR203 exhibits enhanced biological activity in multiple myeloma and neuroblastoma. Pharm Biol 50: 25-29, 2012.

36 Altun M, Galardy PJ, Shringarpure R, Hideshima T, LeBlanc R, Anderson KC, Ploegh HL and Kessler BM: Effects of PS-341 on the activity and composition of proteasomes in multiple myeloma cells. Cancer Res 65: 7896-7901, 2005.

37 Kuhn DJ, Hunsucker SA, Chen Q, Voorhees PM, Orlowski M and Orlowski RZ: Targeted inhibition of the immunoproteasome is a potent strategy against models of multiple myeloma that overcomes resistance to conventional drugs and nonspecific proteasome inhibitors. Blood 113: 4667-4676, 2009.

38 Destanovic E, Boos J and Lanvers-Kaminsky C: Preclinical evaluation of combined topoisomerase and proteasome inhibition against pediatric malignancies. Anticancer Res 38: 3977-3984, 2018.

39 Isono M, Sato A, Asano T, Okubo K and Asano T: Delanzomib interacts with ritonavir synergistically to cause endoplasmic reticulum stress in renal cancer cells. Anticancer Res 38: 34933500,2018 .
Received August 18, 2018

Revised August 27, 2018

Accepted August 30, 2018 